\title{
The impact of maternal obesity on intra-partum events during pregnancy: a retrospective study at Puducherry
}

\section{Ulagammal A.*}

\begin{abstract}
Department of Obstetrics and Gynaecology, Sri Venkateshwaraa Medical College Hospital and Research Centre, Ariyur, Puducherry, India
\end{abstract}

Received: 19 March 2016

Accepted: 25 March 2016

\author{
*Correspondence: \\ Dr. Ulagammal A., \\ E-mail: drdanfi@yahoo.co.in
}

Copyright: () the author(s), publisher and licensee Medip Academy. This is an open-access article distributed under the terms of the Creative Commons Attribution Non-Commercial License, which permits unrestricted non-commercial use, distribution, and reproduction in any medium, provided the original work is properly cited.

\begin{abstract}
Background: Women with excessive weight at the time of conception are prone to a wide spectrum of adverse pregnancy outcomes including major postpartum haemorrhage, increased caesarean section rates, increased operational vaginal deliveries and higher risks of maternal hypertension, gestational diabetes and fetal death.

Methods: This retrospective case-control study was conducted at a tertiary care hospital in Ariyur, Puducherry by comparing 100 obese women (cases) with 100 Non-obese, normal weighted women (controls) in terms their intrapartum pregnancy events and outcomes.

Results: Obese women (42\%) had an increased risk of having a caesarean section (OR 2.57, 95\% CI 1.31-5.1) when compared to the controls $(22 \%)$. Instrumental delivery rate was significantly higher $(\mathrm{p}=0.02)$ in the study group $(24 \%)$ compared to $11 \%$ in the control group (OR 2.56, 95\% CI 1.1-6.1). Postpartum haemorrhage ( $>500$ ml) encountered during vaginal deliveries was $32 \%$ in the obese group which was significantly higher $(\mathrm{p}<0.001)$ when compared with $9 \%$ in the control group (OR 4.76, 95\% CI 2-12).

Conclusions: Obese women had increased incidence of difficult intra-partum events like increased blood loss and post-partum haemorrhage, increased requirement of oxytocin augmentation, higher rates of caesarean and instrumental deliveries, when compared to non-obese women.
\end{abstract}

Keywords: Maternal obesity, Obese and non-obese women, Intrapartum

\section{INTRODUCTION}

Obesity is a modern-day national epidemic which affects all ages and gender in our country which has not spared women of reproductive age also. ${ }^{1}$ Women with excessive weight at the time of conception not only have health problems during gestation and at the time of delivery, but also during the post-partum period. ${ }^{2}$ Various studies done in many parts of the world have demonstrated that obesity in pregnancy is associated with a wide spectrum of adverse pregnancy outcomes including major postpartum haemorrhage, increased caesarean section rates, increased operational vaginal deliveries, higher risks of maternal hypertension, gestational diabetes and fetal death. ${ }^{3-6}$ A study done in urban area of Puducherry showed the prevalence of overweight was $41.4 \%$ and of obesity was $4.5 \% .^{7}$ Another study done in rural areas of Puducherry showed that $27.7 \%$ of the women participants had a BMI $>25 .{ }^{8}$ This shows that there is an anticipated increased risk of obesity inflicted maternal adverse outcomes among women in Puducherry. A healthy dietary plan and physical activity schedule prior to conception can be a useful pre-requisite for women who are obese to save themselves from adverse obesity-related complications during pregnancy. On the other hand, a profile of incident adverse outcomes in obese women during delivery would be useful for obstetricians to anticipate and avert risks in intra-partum period. Hence this study aims at studying the impact of maternal obesity on the various maternal outcomes during pregnancy by 
making a comparison of obese women with non-obese, normal weighted women in terms of the incident adverse maternal intra-partum events.

\section{METHODS}

This retrospective case-control study was conducted at a tertiary care hospital in Ariyur, Puducherry by comparing 100 obese women (cases) with 100 Non-obese, normal weighted women (controls) in terms their intra-partum pregnancy events and outcomes.

Cases were defined as those with a BMI above $30 \mathrm{~kg} / \mathrm{m}^{2}$ at the time of booking with a no other systemic morbidities. Controls were defined as those with a BMI $20-25 \mathrm{~kg} / \mathrm{m}^{2}$ at the time of booking with a no other systemic morbidities. The cases and controls were matched for age, parity, ethnicity, previous obstetric history like caesarean sections and instrumental deliveries.

Data was collected using a proforma regarding sociodemographic details, booking BMI, type of delivery, indication for caesarean or instrumental delivery, episiotomy, post-partum haemorrhage, blood loss and requirement of oxytocin augmentation during delivery.

\section{Statistical analysis}

Data entry and analysis was done using STATA version 13.1. Data is represented as frequencies and percentages. For numerical continuous data, comparison of means was done using unpaired Student's t-test and comparison of two proportions was done by using Z-test for two proportions. Hypotheses concerning count variables were tested using Chi-square test. Odds ratio was computed at $95 \%$ confidence interval to measure the strength of association of any variable with cases or controls. Statistically significance was fixed at $\mathrm{p}=0.05$ for all the tests of hypotheses.

\section{RESULTS}

The study made a comparison between a group of 100 obese women (BMI>30) with an average BMI of 42.7 $( \pm 10.6) \mathrm{kg} / \mathrm{m}^{2}$ and a group of 100 normal weighted women (BMI 20-25) with an average BMI of $23.5( \pm 5.9)$ $\mathrm{kg} / \mathrm{m}^{2}$ (Table 1).

Table 1: Differences in intrapartum outcomes between obese and non-obese women.

\begin{tabular}{|c|c|c|c|c|}
\hline & $\begin{array}{l}\text { Obese Women } \\
(\text { BMI > 30) } \quad n=100\end{array}$ & $\begin{array}{l}\text { Normal Women } \\
\text { (BMI 20-25) } n=100\end{array}$ & $\begin{array}{l}\text { Odds Ratio } \\
\text { OR (95\% CI) }\end{array}$ & $P$ value \\
\hline BMI & $42.7 \pm 10.6$ & $23.5 \pm 5.9$ & & $\mathrm{t}=15.8, \mathrm{p}<0.0018^{\mathrm{a}}$ \\
\hline \multicolumn{5}{|l|}{ Parity } \\
\hline Nullipara & 42 & 38 & & $\mathrm{Z}=0.58, \mathrm{p}=0.56^{\mathrm{b}}$ \\
\hline Multipara & 58 & 62 & & \\
\hline Mean Age & $29 \pm 4.3$ & $28 \pm 6.2$ & & $\mathrm{t}=1.32, \mathrm{p}=0.18$ \\
\hline \multicolumn{5}{|l|}{ Type of delivery } \\
\hline Caesarean & 42 & 22 & $2.57(1.3,5.1)$ & $\chi^{2}=9.19, p=0.02^{c}$ \\
\hline Elective & 22 & 10 & $2.54(1.1,6.4)$ & $\chi^{2}=5.36, p=0.02$ \\
\hline Emergency & 20 & 12 & $1.83(0.7,4.4)$ & $\chi^{2}=2.38, p=0.12$ \\
\hline Normal vaginal & 34 & 67 & $3.94(2.1,7.4)$ & $\chi^{2}=21.8, \mathrm{p}<0.001$ \\
\hline Instrumental & 24 & 11 & $2.56(1.1,6.1)$ & $\chi^{2}=5.85, p=0.02$ \\
\hline Episiotomy & 19 & 16 & $1.23(0.6,2.8)$ & $\chi^{2}=0.31, p=0.57$ \\
\hline \multicolumn{5}{|l|}{ Postpartum haemorrhage } \\
\hline $\mathrm{PPH}(>500 \mathrm{ml})$ & 32 & 9 & $4.76(2,12)$ & $\chi^{2}=16.2, p<0.001$ \\
\hline Major PPH (>1000 ml) & 19 & 6 & $3.67(1.3,11.7)$ & $\chi^{2}=7.7, p=0.05$ \\
\hline \multicolumn{5}{|l|}{ Mean Blood loss } \\
\hline Normal vaginal & $533 \mathrm{ml}$ & $260 \mathrm{ml}$ & & $\mathrm{t}=17.6, \mathrm{p}<0.001$ \\
\hline Elective & $550 \mathrm{ml}$ & $420 \mathrm{ml}$ & & $\mathrm{t}=6.6, \mathrm{p}<0.001$ \\
\hline Emergency & $670 \mathrm{ml}$ & $540 \mathrm{ml}$ & & $\mathrm{t}=8.6, \mathrm{p}<0.001$ \\
\hline $\begin{array}{l}\text { Oxytocin augmentation } \\
\text { during } 1^{\text {st }} \text { stage of labour }\end{array}$ & 29 & 12 & $2.9(1.3,6.9)$ & $\chi^{2}=8.87, p=0.02$ \\
\hline
\end{tabular}

${ }^{\mathrm{a}}$ Student unpaired t-test; ${ }^{\mathrm{b}} \mathrm{Z}$-test for proportions; ${ }^{\mathrm{c}} \mathrm{Chi}$-square test

The mean age of the study group was $29( \pm 4.3)$ years which was not significantly different $(\mathrm{p}=0.18)$ from that of the control group with a mean age of $28( \pm 6.2)$ years.
Among the study group $12 \%$ of women had a booking BMI over $50 \mathrm{~kg} / \mathrm{m}^{2}$ (morbidly obese). The study group consisted of $42 \%$ nulliparous women and $58 \%$ of 
multiparous women, with an identical distribution $(\mathrm{p}=0.56)$ of nulliparous $(38 \%)$ and multiparous $(62 \%)$ women in the control group. Obese women $(42 \%)$ had an increased risk of having a caesarean section (OR 2.57, 95\% CI 1.31-5.1) when compared to the controls (22\%). Among the study group $20 \%$ delivered by emergency caesarean section versus $12 \%$ of the control group (OR 1.83, 95\% CI 0.7-4.4). The incidence of elective caesarean section was also significantly $(\mathrm{p}=0.02)$ higher in the obese group; $22 \%$ versus $10 \%$ (OR 2.54, 95\% CI 1.2-6.4). The normal BMI group (67\%) had a higher propensity to deliver spontaneously by vaginal route compared to the raised BMI group (34\%) (OR 3.94, 95\% CI 2.1-7.4). Instrumental delivery rate was significantly higher $(\mathrm{p}=0.02)$ in the study group $(24 \%)$ compared to $11 \%$ in the control group (OR 2.56, 95\% CI 1.1-6.1). There was not much difference in episiotomy rates between the two groups ( $19 \%$ versus $16 \%, \mathrm{p}=0.57$ ).

Postpartum haemorrhage (>500 ml) encountered during vaginal deliveries was $32 \%$ in the obese group which was significantly higher $(\mathrm{p}<0.001)$ when compared with $9 \%$ in the control group (OR 4.76, 95\% CI 2-12). The incidence of major PPH (>1000 ml) was significantly higher $(\mathrm{p}=0.05)$ in the study group $(19 \%)$ versus $6 \%$ in the control group (OR 3.67, 95\% CI 1.3-11.7) also a significant increase. The mean blood loss at spontaneous vaginal delivery as well as caesarean deliveries was significantly higher $(\mathrm{p}<0.001)$ in the study group than the control group. Oxytocin augmentation was required more frequently $(\mathrm{OR}=2.9$, 95\% CI 1.3-6.9) in obese women (29\%) compared to Non-obese women (12\%) during the $1^{\text {st }}$ stage of labour $(\mathrm{p}=0.02)$.

\section{DISCUSSION}

The average BMI of the obese women participants in the study group was $42.7( \pm 10.6) \mathrm{kg} / \mathrm{m}^{2}$ with $12 \%$ of the participants having morbid obesity (BMI over $50 \mathrm{~kg} / \mathrm{m}^{2}$ ). The BMI profile in this study was similar to the average BMI $(44.5 \mathrm{~kg} / \mathrm{m} 2)$ in the study done by Vinayagam D, et al but morbid obesity was slightly higher in the present study. ${ }^{9}$ Women who are obese are hyperleptinemic. Leptin is an appetite-suppressing hormone produced by adipose tissue and the placenta. It functions as a growth hormone in pregnancy, with maternal levels dropping at birth. Leptin inhibits oxytocin-induced contractions of the myometrium in vitro. ${ }^{10}$ Hence women who are obese have poor uterine contractions leading to increased requirement of oxytocin augmentation during first stage of labour and poor progression demanding need for instrumental or caesarean deliveries. In a study done by Vahratian, et al it was found that among the 600 subjects studied, the progress of labour was much slower with increase in the BMI. ${ }^{11}$ In our study also there was increased requirement of oxytocin augmentation in obese individuals $(\mathrm{OR}=2.9, \mathrm{P}=0.02)$. Further the present study showed a significantly increased number of caesarean deliveries in obese group (42\%) when compared to the controls $(22 \%)$ (OR 2.57, $\mathrm{p}=0.02$ ). Arrowsmith, et al studied 30,000 women in a retrospective cohort study and proved that the obese women who were induced for postmaturity had a higher propensity to go for caesarean deliveries when compared with normal weighted women which was similar to our study. ${ }^{12}$ Increased instrumental deliveries in our study further prove the poor contractility in the obese myometrium of obese women.

\section{CONCLUSIONS}

Obese women had increased incidence of difficult intrapartum events like increased blood loss and post-partum haemorrhage, increased requirement of oxytocin augmentation, higher rates of caesarean and instrumental deliveries, when compared to non-obese women.

A planned midwifery support helps to assure that women who are obese to be able to plan weight reduction before pregnancy. Leptin levels can be brought to normal by proper weight reduction prior to pregnancy. Advising non-exercising pregnant mothers to "take the baby for a walk" (to encourage at least 30 minutes walking/day during Ante-Natal period) improves their aerobic capacity for labour.

\section{ACKNOWLEDGEMENTS}

I sincerely thank the Post- graduate students and Interns of the Department of Obstetrics and Gynaecology and the management of Sri Venkateshwaraa Medical College Hospital and Research Centre, Ariyur, Puducherry for their significant contribution in conducting this research.

Funding: No funding sources

Conflict of interest: None declared

Ethical approval: The study was approved by the Institutional Ethics Committee

\section{REFERENCES}

1. Flegal KM, Carroll MD, Ogden CL, Johnson CL. Prevalence and trends in obesity among US adults, 1999-2000. JAMA. 2002;288:1723-7.

2. Hilson JA, Rasmussen KM, Kjolhede CL. Excessive weight gain during pregnancy is associated with earlier termination of breast-feeding among white women. The Journal of nutrition. 2006;136(1):1406.

3. Ramsay JE, Greer I, Sattar N. ABC of obesity. Obesity and reproduction. BMJ. 2006;333:1159-62.

4. Heslehurst N, Simpson H, Ells LJ, Rankin J, Wilkinson J, Lang R. The impact of maternal BMI status on pregnancy outcomes with immediate shortterm obstetric resource implications: a metaanalysis. Obes Rev. 2008;9:635-83.

5. Cedergren MI. Maternal morbid obesity and the risk of adverse pregnancy outcome. Obstet Gynecol. 2004;103:219-24. 
6. Johnson JW, Longmate JA, Frentzen B. Excessive maternal weight and pregnancy outcome. Am J Obstet Gynecol. 1992;167:353-70.

7. Rajkamal R, Singh Z, Stalin P, Muthurajesh E. Prevalence and determinants of overweight and obesity among elderly population in an urban area of Puducherry. Int $\mathrm{J}$ Med Sci Public Health. 2015;4(3):369-72.

8. Shrivastava SR, Ghorpade AG, Shrivastava PS. Prevalence and epidemiological determinants of obesity in rural Pondicherry, India-A community based cross-sectional study. Al Ameen J Med Sci. 2015;1(8):3-10.

9. Vinayagam D, Chandraharan E. The Adverse Impact of maternal obesity on intrapartum and perinatal outcomes. ISRN. Obstetr Gynecol. 2012;2012:1-5.
10. Cecilia J, Ivonne H, Maureen G. Lactation Complicated by overweight and obesity: supporting the mother and newborn. J Midwifery Womens Health. 2007;52(6):606-13.

11. Vahratian A, Zhang J, Troendle JF, Savitz DA, Siega-Riz AM. Maternal pre-pregnancy overweight and obesity and the pattern of labour progression in term nulliparous women. Obstetr Gynecol. 2004;104(5):943-51.

12. Arrowsmith S, Wray S, Quenby S. Maternal obesity and labour complications following induction of labour in prolonged pregnancy. An Intern J Obstetr Gynaecol. 2011;118(5):578-88.

Cite this article as: Ulagammal A. The impact of maternal obesity on intra-partum events during pregnancy: a retrospective study at Puducherry. Int $\mathbf{J}$ Reprod Contracept Obstet Gynecol 2016;5:994-7. 